\title{
Jazz in Jakarta: a Challenge for Tourism In the fast-transforming City
}

\author{
Dr. Marie-Christine Bonneau \\ UFR ESTHUA To Tourisme et Culture \\ Université d'Angers, France \\ marie-christine.bonneau@univ-angers.fr
}

\author{
Dr. Asep Parantika \\ Sahid Institute of Tourism \\ Tangerang Selatan, Indonesia \\ asepparantika@stpsahid.ac.id
}

\begin{abstract}
Jakarta as the core of Java Mega-Urban Region has become an unavoidable stopover on tourist routes. Musical events -as Jazz festivals - in the fast-transforming metropole do attract an ever-increasing number of visitors from the Asia Pacific area, and even further. Tourism managers must from now on face up with the challenge of upgrading Jakarta to a top Music Destinations in South East Asia. The paper focuses on the interactions of Tourism with the developing urban and musical culture of Indonesia Capital City.
\end{abstract}

Keywords-Jakarta; Musical Heritage; Jazz Festival; Destination Management; Urban culture; Global culture.

\section{INTRODUCTION}

Jakarta DKI (Daerah Khusus Ibukota, Special Capital District) is not normally considered as a tourist destination. Authors indicate that the progression of tourist arrivals remains low compared to other provinces. Traffic, waste management, flooding or the lack of drinkable water are still crucial issues for both tourists and residents. However, Jakarta - at the crossroads of international routes - welcome quite a number of domestic and international tourists each year. In 2014, Soekarno-Hatta International Airport offered almost 1,200 scheduled flights every day (Airport Council International). Thirty eight international airlines develop a regular service from/to Jakarta covering 33 capital cities. According to the Central Statistics Bureau (BPS) ${ }^{i}$, the number of tourist arrivals rose by 26.79 per cent to Tanjunk Priok seaport, and by 9.67 per cent to Soekarno-Hatta in 2014. In 2015, the Indonesian government has allowed foreign-flagged tourist cruise ships to call at Jakarta Tanjung Priok (together with three other ports) in addition to the current Benoa port in Bali to respond to the upward trend of foreign tourists and foreign cruise liners visiting Indonesia (Decree No. PM 121 Year 2015).

Jakarta offers traditionally five main attractions: Ancol Beach, Old Town (Kota), National Monument (Monas), Ragunan Zoo and Indonesia Miniature Park (Parantika, 2015) ${ }^{\mathrm{ii}}$. Those attractions are recommended by guidebooks and cruise lines brochures together with city icons as Kempinsky Tower or brand new commercial centers. Jakarta
Intangible Heritage and Urban Culture do however appear as a key element of the city attractiveness as Jakarta states as one of the main city in South East Asia for organizing musical events all the year around that take place in Jakarta South (Bulungan Outdoor) or Jakarta Fairgrounds in Kemayoran, or Ancol Eco-Park in the North (close to Tanjunk Priok seaport). For instance, the Hammersonic in April became a main Metal music event while Java Rockin'Land entices each June since 2009 the audience to a night of Rock \& Roll; Djakarta Warehouse Project in December welcomes World famous DJs to entertain an increasing public.

Java Festival Production (JFP), created in 2004 held in March 2005 its first annual Festival known as Java Jazz Festival for three days in Jakarta Convention Center. The number of visitors to Java Jazz Festival jumped from 40000 in 2004 to 150000 visitors in $2011^{\text {iii }}$. Jakarta Jazz Festival the second big Jazz event in Jakarta - is organized by Jak jazz Production since 1988 and held every year in October. We can also observe in Jakarta the spreading over of formal and informal venues for occasional jazz events, especially in the middle-class South Jakarta neighborhood (Komunitas Café and Jazz Bar in Fatmawati Commercial Complex, Largo Bistrot on Benda Raya Street or The Red White Lounge in Kemang area, Black Cat and Blues Bar on Plaza Senayan Mall Complex) $)^{\text {iv }}$.

In this study, we will focus on the following issues:

- What do Jazz festivals bring to the city image? How do jazz events interfere with the promotion of a more traditional musical heritage, like Betawi music heritage list edited by the Culture Department of Jakarta DKI in $2000^{\mathrm{v}}$ ?

- How do jazz events integrate in the city development to insure visitors and residents a quality experience (access to venues, safety and quality of social interaction)?

- How can the study of jazz events in the city environment (and more generally, musical events) help improve methods to understand the 
dynamics of social interaction in a fast-growing urban environment?

\section{EMERGENCE OF JAZZ IN JAKARTA MUSIC}

The context of Jakarta Jazz Festival (Jak Jazz) creation in 1988 is very different from Java Jazz development from 2004. The urban audience for Jazz music developed in Indonesia from the late 1960s-during President Suharto New Order" regime - simultaneously with the widening of music styles on the Indonesian scene: Western-influenced Rock, Jazz and Pop groups became fashionable blared over radio and television. When heavy metal and hard rock appeared since then the most popular genres among both rural and urban youth together with sentimental love songs, Western jazz is more the preferred music of the cultural and economic elite, and considered as a prestigious popular music (Wallach, 2008) ${ }^{\mathrm{vi}}$ : the audience for instrumental jazz however always remained limited in the country.

Many Indonesian jazz players developed a jazz-pop fusion music, performing on pop albums or combining jazz with traditional Indonesian music to reach an international audience. One of the main figures of Indonesian jazz is Ireng Maulana (who died in March, 2016): in 1978, he founded the group Ireng Maulana All Stars" that continued to grow until the formation of Ireng Maulana Associates, an organization that joins the jazz musicians in Jakarta and was the founder of Jakarta Jazz Festival (Jak Jazz) in 1988.

In 2004, Java Jazz Festival was created by Peter F. Gontha ${ }^{\text {vii }}$ using the model of Rotterdam North Sea Jazz ${ }^{\text {vii }}$ as well as Montreal (Canada) Jazz Festival ${ }^{i x}$. One of the objectives was to bring Jakarta up to the level of the main creative capitals, offering the image of an attractive and safe city in the post-2004 tsunami (in Aceh) as well as the postBali terrorist attack context. To attract the younger generations, Java Jazz Festival include pop musicians and also contemporary young musicians, for instance the group Maliq and d'Essential, considered as capable of connecting jazz music with pop music or the young bassist Barry Likumahuwa (born in 1983) who formed Barry Likumahuwa Project in 2006 which combines Funk and soul rhythm, harmony and melody with jazz .

\section{A. Jakarta as a cradle of Music syncretism}

Although jazz concerts in Jakarta are not designed for the mass audience, jazz music contributes to the image of Jakarta as a cradle or crossroads of diverse traditions. Since the foundation of Batavia in 1609, the city has been a cradle of street music styles imported from rural areas.

In 2000, Culture Department of Jakarta Province (Dinas Kebudayaan, Propinsi DKI Jakarta) published the list of Betawi (descendants of Batavia inhabitants) musical heritage which include samrah dance, jaipongan, Marawis Orchestra, Tanjidor Orchestra or Melayu Orchestra among others). By retracing the origins of each musical form or performance outside of Batavia (villages, islands, countries where the migrants came from), or observing the influences received from Western, Indian, Arab or Chinese music styles, we can state that Batavia and then Jakarta was throughout history a place for musical syncretism ${ }^{\mathrm{xi}}$. After Indonesian Independence, and despite of President Suharto's crusade against Western influences ${ }^{\text {xii }}$, urban spaces -either formal or informal- devoted to musical expression and commerce boomed up in Jakarta.

Musical heritage and expression in the city - either it raises cultural conflicts or re-creates cultural identity participates to urban identity, performing arts being able to reconstruct in the city environment collective memories as Jorge Santiago has shown with his study of music and sociability in Campos, Brazil (Santiago, 2000) ${ }^{\mathrm{xiii}}$.

\section{B. Music and Mobility}

We want to underline in this study that city jazz - among other musical genres - reinforce a cosmopolitan and sociable image of the city, opening spaces for social interaction - within a certain control - and fostering the resident and traveler mobility in and out the place.

- Although apparently fragmented at the moment, Jakarta musical scene is progressively shaping itself into a significant network or chain of events with music as a core element: for instance, Jakarta Fair celebrating the city Anniversary, Jalan Jaksa Street Fair celebrating Betawi music, Jakarta Parade on Independence Day but also main Indorock or IndoPop events. To mention Metal Rock as another example of Indonesian booming-up music, almost 900 bands were registered on the Encyclopaedia of Metal Music in 2014, twice more at least than in the other ASEAN countries.

- A complete geography of music venues in Jakarta would show a large variety of types of places (with various local centers) devoted to music, under formal or informal social control, and offering a complex social and spatial structure; fluidity, flexibility and impermanence would probably strike the spatial patterns of such a geography.

- Such events attract visitors from ASEAN countries but also from much further with fans all over the planet joining social networks on-line. Java Jazz as other main events provide live streaming on-line of the concerts; global networks are then used as spaces for creativity but as music fans know, nothing can replace a live concert. On-line networks engender tourist physical mobility and visits to concerts.

\section{JAZZ AND DESTINATION MANAGEMENT}

Jazz brings to Jakarta a positive aura: Jazz music appears as an art of diplomacy, a unifying force celebrating diversity and freedom. Jakarta DKI local authorities and the Ministry of Tourism in Indonesia are most aware of it, supporting such festivals with tax reductions and outdoor promoting on the main city avenues (Sudirman Boulevard, Thamrin 
Street). In 2016, the Ministry of Tourism also Borobudur Jazz Festival (each November, in Magelang), Jazz Gunung Bromo (each August, Eastern Java), Jazz ljen Festival (each September, in Malang) and Jolo City Jazz (each September, in Solo) ${ }^{\mathrm{xiv}}$.

The biggest support to city events comes from private stakeholders, not from the State. Majors industry partners at national scale are used to sponsor such events: especially the Teh Sosro Drink Company, Bank Nasional Indonesia, Garuda Indonesia Airlines. Indonesia's major tobacco companies-Sampoerna, Gudang Garam, Djarum and Bentoel - were the biggest sponsors (of sport and music events in Indonesia) till 2014, when the new policies on tobacco control came into effect.

This major change is a new turn and definitely aims at bringing Indonesia in line with international standards: it shows the will to set Jakarta international events in accordance with the global culture. The support of any event in Indonesia by the Ministry of Tourism is conditioned by three main criteria: event quality and cultural impact, commitment of organizers and event regularity ${ }^{\mathrm{xv}}$.

\section{A. The image of a secure and international city}

To show the world that Jakarta is a safe, livable and joyful city is one of the objectives of Java Festival Production, the organization which also manages Rock in Land and Java Soul Nation festivals.

In order to invite international artists, JFP closely works with Embassies: in march 2016, Java Jazz welcomed Enrico Rava (an italian jazz trumpeter), through a partnership with the Embassy of Italy and the Italian Culture Institute of Jakarta but also Eos Músicos de José”, a Mexico City band with the support of the Embassy of Mexico. With the support of the Embassy of India, JFP also hosted Joe Alvares a Western Vocalist in the Country, registered with Indian Council for Cultural Relations.

\section{B. A regional target}

The target of jazz festivals - especially of Java Jazz - is a regional market: the challenge is to become the leader of Jazz festivals in ASEAN, and compete with Singapore and Malaysia. Java Festival Production cooperates to achieve this goal with Singapore to organize Sing Jazz Festival and which takes place in the same period than Java Jazz (March or April each year). Java Jazz welcomes 35 to 40 international artists or groups each year, promoted outdoor but also on social media (Twitter, Facebook, Path, Instagram) with a large impact on the Asia Pacific region. In terms of socio-graphics, the focus groups belong to the South East Asian middle class or upper class with ticket pricing ranging from 40 to 50 Euros per concert (half-price compared with the ticket price for a main East Asian pop star concert). Australia, the U.S, United Kingdom, Germany and the Netherlands are the five main home countries of Java Jazz and Jak Jazz non-Asian audience: countries where the city jazz culture was born or became traditional, hosting the most famous jazz festivals.

\section{Multi-staged events}

Java Jazz is designed from the concept of North Sea Jazz, a three-day multi-staged event. Starting with 21 different stages, the festival was limited to 17 stages and finally to 12 stages only nowadays. From 2005 to 2009, Java Jazz was held in Jakarta Convention Center (JCC) - located in the city commercial center - but in 2010 it moved to Jakarta International Expo (JI Expo, Jakarta North) which has a greater capacity and the facilities of a brand new convention center. Pre-event venues are organized on 12 stages covering the different city areas (North, West and Central Jakarta) but also, on a larger scale, the suburbs of Tangerang (West of Jakarta), Depok (South of Jakarta) where University of Indonesia Campus is located.

\begin{tabular}{|c|c|c|}
\hline $\begin{array}{c}\text { Name } \\
\text { Of } \\
\text { Venue }\end{array}$ & City location & Venue type \\
\hline $\begin{array}{l}\text { Jakarta International } \\
\text { Expo }\end{array}$ & Pademangan, Jakarta North & Pre-event \\
\hline $\begin{array}{l}\text { Motion Blue Jakarta - } \\
\text { Fairmont Hotel }\end{array}$ & Jakarta Pusat (Centre) & Pre-event \\
\hline Hotel Borobudur Jakarta & Jakarta Pusat (Centre) & Pre-event \\
\hline $\begin{array}{l}\text { BNI Office - Parking } \\
\text { Area }\end{array}$ & Jakarta Pusat (Centre) & Pre-event \\
\hline $\begin{array}{lcl}\text { Grand } & \text { Atrium } \\
\text { Supermall Karawaci } & \end{array}$ & Tangerang (Western Suburb) & Pre-event \\
\hline $\begin{array}{lrr}\text { Broadway } & \text { Stage } & - \\
\text { Summarecon } & & \text { Mal } \\
\text { Serpong } & & \\
\end{array}$ & Tangerang (Western Suburb) & Pre-event \\
\hline $\begin{array}{l}\text { The Expansion - Puri } \\
\text { Indah Mall }\end{array}$ & Jakarta Barat (Jakarta West) & Pre-event \\
\hline $\begin{array}{l}\text { La Piazza - Kelapa } \\
\text { Gading }\end{array}$ & Jakarta Utara (Jakarta North) & Pre-event \\
\hline $\begin{array}{l}\text { Outdoor Event Plaza - } \\
\text { AEON MALL BSD }\end{array}$ & Tangerang (Western Suburb) & Pre-event \\
\hline $\begin{array}{l}\text { Amphitheater } \\
\text { Teraskota, BSD City }\end{array}$ & Tangerang (Western Suburb) & Pre-event \\
\hline $\begin{array}{l}\text { Ozone Area - Margo } \\
\text { City Depok }\end{array}$ & Depok (Southern Suburb) & Pre-event \\
\hline $\begin{array}{l}\text { Butterfield Jazz Society } \\
\text { - Jl. Dipatiukur no. 5, } \\
\text { Bandung }\end{array}$ & Bandung City, West Java & Pre-event \\
\hline
\end{tabular}

Fig. 1. Java Jazz Pre-event Venues 2016

Two venues take place at the outskirts of Jakarta DKI (in Banten Province) and one venue is even located in Bandung. Multi-staged (free) concerts in city parks correspond to an international model (North Sea Jazz Festival for instance); in Jakarta, this model is not applicable (due to the city configuration but also street policies); pre-event concerts are then spread over the province, and even out of the limits of the province. The cartography of Java Jazz pre-event venues show an expanding network of various local centers: JI Expo, Fairmont (\& main Hotels) area, Puri Indah Mall in Jakarta West, Karawaci Mall in Tangerang, Ozone Area (close to UI Campus) in Depok and Bandung (recently listed by 
UNESCO as a Creative City), in West Java. The venues are not permanent (changing every year): the cartography of Java Jazz venues over the last ten years is a very fluid and on the move.

\section{CONCLUSION}

Music in the city is an interesting object of study for urban geographers because such an interrogation leads to questioning space representations and definition. ${ }^{\mathrm{xvi}}$ Music is in itself a syncretic art enriching itself with contacts with otherness, tourist and musician mobility and exchanges. Musical events in a fast-growing city like Jakarta - core of a Mega-Urban Region - underline contemporary urban life and search for sociability and interconnections.

Indonesia is aiming at welcoming 20 million tourists in 2019 in ten major destinations and is developing a multisectorial plan (for transport, public service, forestry management, natural resources, culture and education improvement). Transforming Jakarta Kota (the Old City) into a Manhattan", in collaboration with experts and private stakeholders, appears to be the plan for the future: the promotion of Jazz in Jakarta, among other genres of contemporary and pop music, plays a crucial role in this scheme.

\section{REFERENCES}

i Badan Pusat Statistik, International Visitor Arrival Statistics, 2014

ii A. Parantika, Le Tourisme Domestique Indonésien entre Transfert et Innovation, vers un nouveau modèle?, Ph. D. Thesis, University of Angers, 2015.

iii https://www.javajazzfestival.com read on 5, April 2016

iv The Jakarta Post, « Jakarta's Jazz joints », 7 March 2014

${ }^{v}$ Dinas Kebudayan, Provinsi DKI Jakarta, Musik dan lagu rakyat dari tengah Kota Jakarta, Ridwan Saidi (ed.), 2000

${ }^{v i} \mathrm{~J}$. Wallach, Modern noise, fluid genres : popular music in Indonesia, 1997-2001, The University of Wisconsin Press, Madison, pp. 190-209

vii http://jakarta.globe.beritasatu.com/business/peter-gonthaleaves-first-media/

viii http://northseajazz.com/en/

${ }^{i x}$ http://montrealjazzfest.com/default-en.aspx

${ }^{\mathrm{x}}$ Interview conducted with Mr. Ressanda Tamaputra, Head of Promotion of Java Festival Production on 15, March 2016

xi For history of Indonesian performing arts, see «Indonesian Heritage: Performing Arts », Prof. Edi Sedyawati (ed.), Archipelago Press, 1998.

${ }^{x i i}$ C.A. Lockard, Dance of life : Popular Music and Politics in Southeast Asia, University of Hawai'I Press, Honolulu, 1998, pp. 54-113 xiii J. Santiago, La musique et la ville: Sociabilité et identités urbaines à Campos, Brésil, L'Harmattan, Paris, 2000.

xiv Activity plan for 2016, Development Plan by Market Segment, Deputy for the ArchipelagoTourism Marketing, Deputy Minister Office, collected on 12, April 2016

xv Interview conducted with Mr. Dadang Rizki Ratman, Deputy-Minister of Tourism in charge of Destination Management and Tourism Industry on 13, April 2016.

xvi Y. Raibaud, «Musiques et territoires: ce que la géographie peut en dire », Conférence d'ouverture du Colloque international de Grenoble «MUSIQUE, TERRITOIRE ET DEVELOPPEMENT LOCAL », on November, 19 \& 20 2009, organized by CNRS PACTE, UMR n5194, 2009 